University of Pennsylvania Carey Law School

Penn Law: Legal Scholarship Repository

Faculty Scholarship at Penn Law

1997

\title{
Nest Eggs and Stormy Weather: Law, Culture, and Black Women's Lack of Wealth
}

\author{
Regina Austin \\ University of Pennsylvania Carey Law School
}

Follow this and additional works at: https://scholarship.law.upenn.edu/faculty_scholarship

Part of the African American Studies Commons, Civil Rights and Discrimination Commons, Family Law Commons, Inequality and Stratification Commons, Law and Gender Commons, Law and Society Commons, Public Economics Commons, and the Race and Ethnicity Commons

\section{Repository Citation}

Austin, Regina, "Nest Eggs and Stormy Weather: Law, Culture, and Black Women's Lack of Wealth" (1997). Faculty Scholarship at Penn Law. 813.

https://scholarship.law.upenn.edu/faculty_scholarship/813

This Article is brought to you for free and open access by Penn Law: Legal Scholarship Repository. It has been accepted for inclusion in Faculty Scholarship at Penn Law by an authorized administrator of Penn Law: Legal Scholarship Repository. For more information, please contact PennlawIR@law.upenn.edu. 


\title{
NEST EGGS AND STORMY WEATHER: IAW, CULTURE, AND BLACW WOMEN'S LACK OF WEALTH
}

\author{
Regina Austin :
}

Sési" eggr. mone"y silved and held in resere for emergencies, retirement. etc.'

Mise men say

Reep something til a ram dar:

Dont know why there s no sum up in the sky,

Stormy weather.

since my man and I an together.

Leeps ramin all the tinte.

Vest eggs are supposed to provide protection against a raing dat, but suppose it rans all the time: I know I am mixing metaphors or whatever, but that is black women's fate in America, is it not? Are our lives not what happens when Poor Richard's Almanar rums up against the Plues?

There ane many rass w think doont black women and economic or distributive justice, but the best war to do it may be in tems of savings asset acomulation. or simply put wealth. Black romen hate been in the red, asset-rise, since our ancestors were bonght here as someone else's property. Things might have impared if the freed shases had been given the forty acres and a

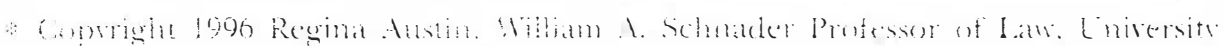

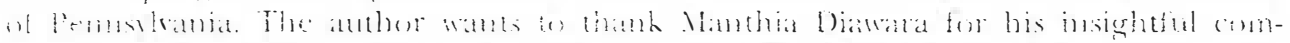

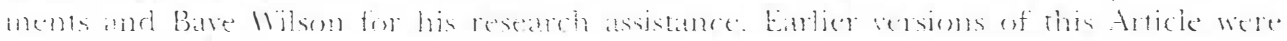

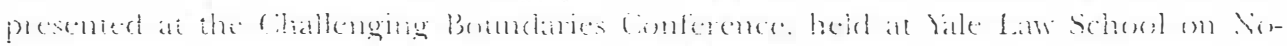

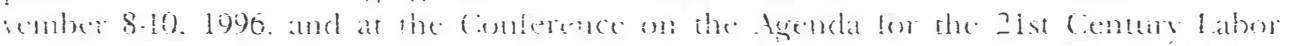

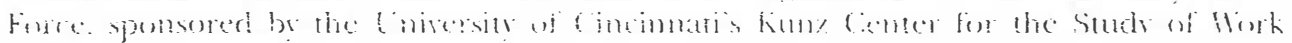
and Famila and held on volumbe $15-17.1996$.

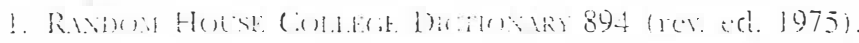

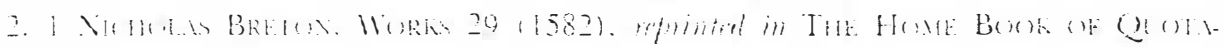

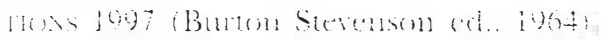

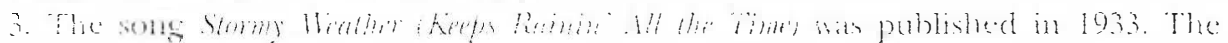

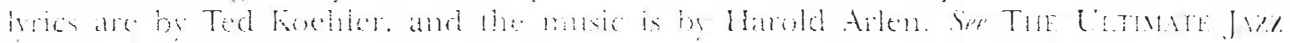

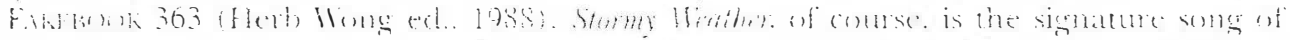

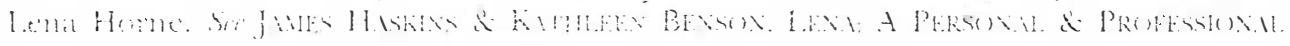

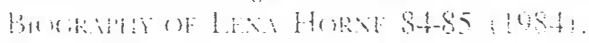


mule they were promised, but that nerer materialized. ${ }^{+}$Because I very much doubt that reparations of that or any other kind will be forthooming in the near future, it belhoores us to gire some thought to other means of augmenting black women's wealth.

Although some attention has focused on income inequality between black women and others, more study needs to be clirected at wealth inequality across race and gencler lines. "[W] ealth is one inclicator of material disparity that captures the historical legacy of low wages, personal and organizational discrimination, and institutionalized racism" to which black women have been subjected in this country As a general matter, the significance of wealth to well-being in ou consumption-oriented society tends to be underestimated. Moreorer, exploring policies that impact on the distribution of the wealth across racial and gencler groups is far scarier than discussing measures for equalizing income. Yet, assets, not income, assure class mobility: It is the redisu ibution of the wealth, not the reallocation of income, that is likely to procluce changes in the class positions of black women and their children. Indeed. if the women who are now receiving public assistance are to achieve the level of self-sulficiencr really required to end welfare as we know it, then we must begin to consider creating mechanisms by which ther can acquire weath to insure their futures.

My dictionary defines wealth as "a great guantity or store of money or property." Then I use the tem "realth" howerer, I am referring to something more modest. basically accmmated assets. Wealth is what is left orey after the bills are patid. It is

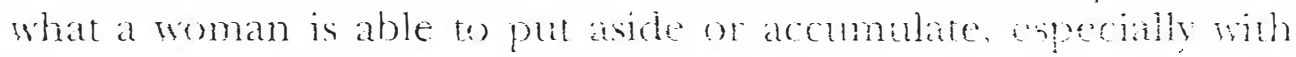
her employer's assistance. It is rohat a woman wemes less what a woman oilles.

Economists hate arion was of categorizing and meastring wealth that may be tostul for my puposes. Coneraly, wealth is the value of total assets less wal debt at a fixed point in time. For the very rich, assets may consist largely of stocks, bonds. trust funds, business equity, and nonrestential real estate. For the nonwealthy, which is to say mosi of us, assets include residential

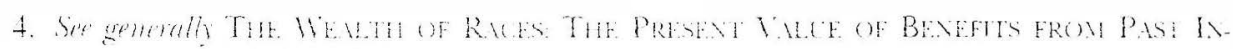

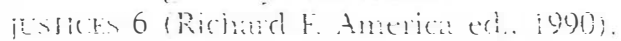

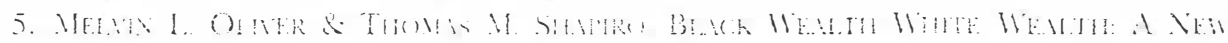

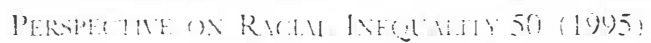

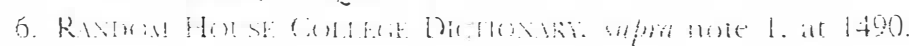

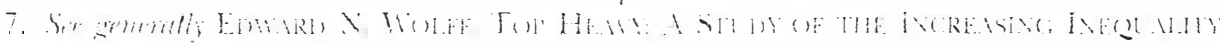

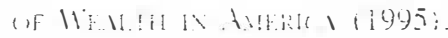


property; automobiles; deposits held in bank accomts, money market funds, and certificates of deposit: and indiridually-held retirement accounts. Some measures of wealth include employersupported or controlled pension funds, the cash surrender value of life insurance policies, and durable goods, while others do not. Debt typically consists of mortgages, loans. or other obligations owing to banks, mortgage companies. credit unions, or finance companies as well as the balance due on credit card, retail store, or gasoline charge accounts.

It is not easy to determine exactly how much wealth black women possess or control. Some of the crucial data is collected separately by race and by gender, with data pertaining to black women being included in both categories. The available wealth statistics, nonetheless, suggest that black women's holdings are quite limited.

First, consider household realth by race. Keep in mind that, in the period generally applicable. fomale-headed households constituted roughly forty-eight percent of all black households. compared with fourteen pereent for whites." Moreorer, black women theoretically have control over the wealth held by black married households.

In 1993, white househoids had median measured net worth of $\$ 45,740$, while black households had median measured net rorth of $54,418 . "$ White households had substantially higher median measured net worth than black households in evere income quintile. In the highest quintile. the median net worth of whites was $\$ 123,350$ and that of blacks was $\$ 45,023 . "$ In the lowest quintile. the median net worth of whites was $\$ 7.605$, compared with $\$ 250$ for blacks. "The $\$ 250$ higme represented an improsement from 1991 when the median met woth of black households in the lowest quintile was measued at erero dollars!?

Although I do not have 1993 data on the net worth of families headed by black females alone, femalcheaded households in

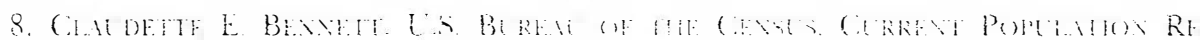

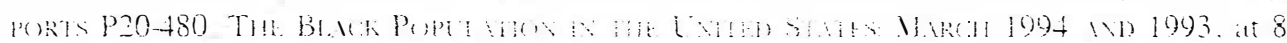
(b).E (1995).

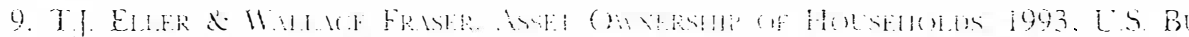

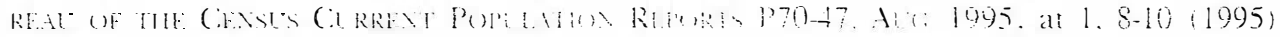

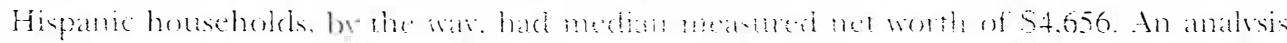

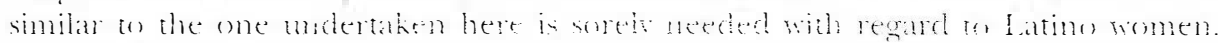

10. Sere ial. at 10

11. Sire id at 9 .

12. Sir id. 
general had a net median worth of $\$ 13,294$ as compared with $\$ 61,905$ for married-couple households. ${ }^{13}$

Data from 1988 may be useful in completing this rough portrait of black women's wealth. ${ }^{14}$ Note that in 1988 maried couples were only thirty-five percent of black households, compared with about sixty percent of white households. Black married-couple households had median net worth of $\$ 17,635$, compared with $\$ 62,386$ for their white counterparts. Households maintained by black females had a median household net worth of $\$ 757$. compared with a median net worth of $\$ 22,099$ held by white female households.

Older, nommarried black women are particularly poor in terms of assets. In 1994, only thirty-two percent of black nonmarried women sixty-five and older received income from assets, compared with sixty-three percent for their white female counterparts. ${ }^{15}$ Indeed, income from assets constituted only $3.4 \%$ of nommarried black women's income as opposed to $20.1 \%$ of white women's income. ${ }^{16}$ Only twelve percent of nommarried black women sixty-five and over received income from a prirate pension or annuity, whereas twenty-two percent of nonmarried white women, twenty-seven percent of black married couples, and fortytwo percent of white married couples did so. ${ }^{17}$ In general, older nonmarried black women were more dependent upon social security, government employee pensions, earnings, and welfare than white women. ${ }^{18}$

The bottom line, then, is that black females seem to control very little wealth. As a result, many black women do not enjoy the numerous advantages that come with owning assets. Sickness. disability, death, unemplorment, other forms of job instability, childbirth, separation, or divorce can threaten the security of a black woman and her family. Material wealth provides some protection against unexpected changes in the amount and flow of income and expenditures due to such changes in a woman's life circumstances. Assets also facilitate future consumption, particu-

13. Sir id. at 10 .

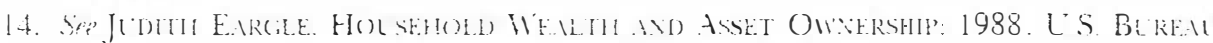

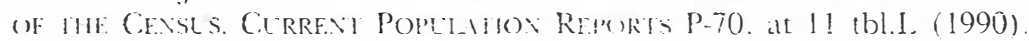

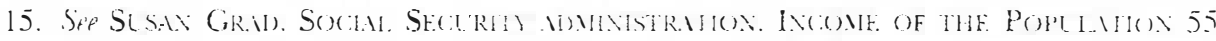

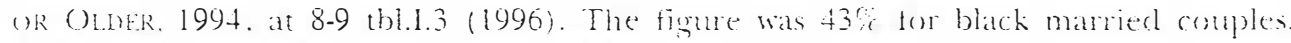
32 . for white married couples, and $26 \%$ for nommanied black men.

16. Sore irl. at 112 ibl.VII.t.

17. Site id. at 8-9 (b) I.1.3.

18. Sie irl. at 112 blol.3. 
larly of expensire items like a car, a house, or a college educat tion for one's self or one's children. Wealth aho provides the foundation for the risk taking and entreprenemship that can generate greater income and increased wealth. At some point, most people's wage earning capacity ends; wealth in the form of savings or pension benefits eases existence during retirement. Finally, wealth provides a legacr for one's children in sereral wass. Children whose families have assets are more likely to maintain the class standing of their parents, if not move higher in the class hierarchy than children from families who mar hate comparrable incomes and occupational attaimment. but possess ferer assets. ${ }^{19}$ If their parents or their families have assets. young people can look to those assets for assistance in pursuing higher education, establishing families of their orm. purchasing a home. or starting a business. ${ }^{20}$ Finally, inherited wealth provides the foundation for the asset base on which each succeeding generation ()ptimizes the life chances of its offspring.

In addition to its material value, wealth has psychic social and political advantages. Joe Lewis is reponted to have said. "I don't like money actually, but it quiets my neres." A t woman who possesses weath has greater control ore her welfare and circumstances and greater cause for peace of mind."- Wealth increases one's ability to plan for the future. In late it increases ones stake in and connection to the future. Wealth can also expand? one's social poiver and intluence. People with wealth maly also have a greater stake in the political ststem and in preserting the relative status quos.

In sum. "assets improre ecomomic stability: commect perple with a vable. hopeful future; stimulate derelopment of human and other capital; enabie people to focus and specialize; provirle a founclation for risk taking; vield personal, social. and political rlividencls: and entance the welfare of uffipring. "? These bene-

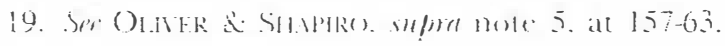

20). Sim at 152 .

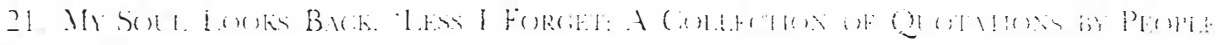

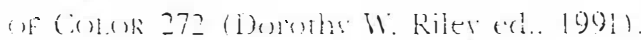

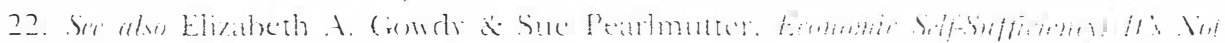

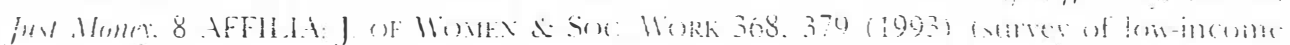

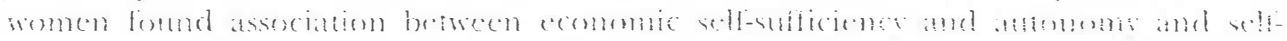

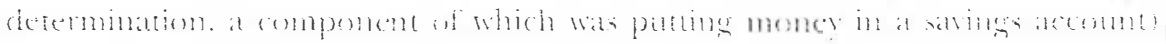

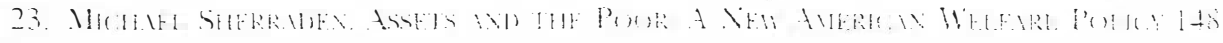
(1991). 
fits of wealth are largely missing from the lives of black women who do not hare assets.

Explanations for black romen's lack of wealth fall into tw broad categ-ries that differ according to the degree of contr -r agency that they assume black women have orer their asset accumulation. One set of reasons focuses $\bullet$ institutional and structural impediments to black women's wealth acquisition. The second set of rationales considers indiviclual and cultural rariables that impact negatively on black romen's clesire or capacity to save. ${ }^{2+}$

In my view, structural impediments to black women's wealth accumulation on the one hand, and individual and cultural factors on the other, are dialectically related. Material conditions create cultural and psrchøogical responses that, in turn, take $\bullet$ a life of their own, impacting on, as well as adapting themselves to, the material world. Nonetheless, more research needs to be done on the culumal and psychological factors affecting black women's wealth accumulation because chey are erected as a significant impediment to the adoption of reforms of the structural obstacles.

The structural or institutional hypothesis starts with the assumption that asset accumulation is not simply a matter of saring, nest egging, or strimg. According to economist Michat Sherraden. "In most households mustrucured savings out of the - rdinary income streams is insignilicant compared to institutionalized asset accumulation." " Sarng most often "enter households through various insiaturonal arangements [whereby] [m]oner is grided divecty inco asset accumulation, and subsiclized in the process." "Fhus, the butk of the net worth of most households consists of housing equity and retirement or pension holdings. Housing equity is subsidized by the federal income tax deductions for home mortgage interest and real estate taxes, ${ }^{2}$ as well as by limitaions on the recognition of gams from the sale of a principal residence "." Taxes are doffred on contributions to

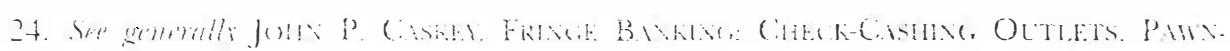

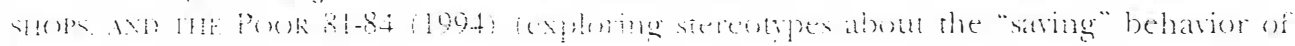
low-income people).

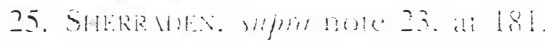

20. $i 1$.

27. Se R.C. $\leqslant 163(\mathrm{~h}) \mathrm{H}$ (h)(2)(b).

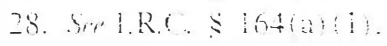

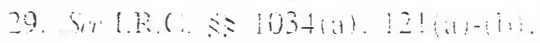


pension plans, ${ }^{30}$ tax deferred annuities, ${ }^{31}$ individual rerirement accounts, ${ }^{32}$ and Keogh plans. "33 Emplovers mav deduct contributions to qualified emploree pension plans. ${ }^{3+}$ Of course, the ease with which workers can participate in these forms of asset accumulation facilitates their utilization.

As the discussion that follows indicates, black women are not substantial beneficiaries of the principal forms of government subsidized asset accumulation, nor of other kinds of institutional privileges that facilitate wealth accumulation, such as beneficial tax treatment of gifts and capital gains or emplovee-sponsored he'alth and life insurance. ${ }^{35}$

"One road to wealth is long-term steady emplorment in the kinds of work organizations that offer job-sponsored benefits and retirement packages." 3 That is, unfortunately, one path to "ealth from which black women have been foreclosed until ver recently. Black women todar eam roughly sixu-three percent of the median weekly earnings of white men. ${ }^{37}$ The width of the contemporary gap between black female wage-eamers and white men reflects vast improvements in the position of black women in the labor market. Historically, the difference botween black female eamings and white male eamings was much greater. This gap has had a dewatating impact on black women's wealth. "[O] rer the rears these earnings shortfalls have resulted in less savings, less investments, and less transfers to slicceeding generat toms. Orer time, less income can result in vast dilferences in atsset accunulation." "s

In addition an low wayes, black women suffer from greater job insecurity that is atributable to unemplovment and to temporme or combingent emplorment that interrupts the low of income and impedes the building of assets. Though I do not hate exact figmes to support the claim, it appears that substantal mumbers

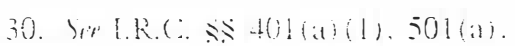

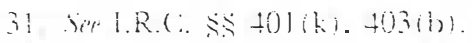

32. SH PR. S S $21 \% 408$

3. S. S I.R.C. $\$+0) 1(0)$

34. S R R $(2 \leq 404(a)$.

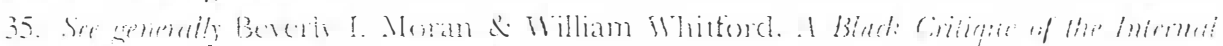

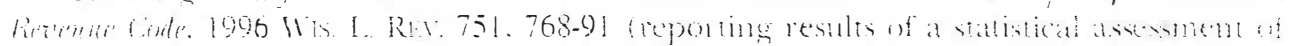

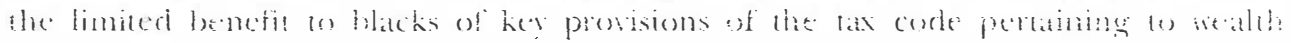
accumatation)

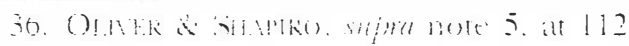

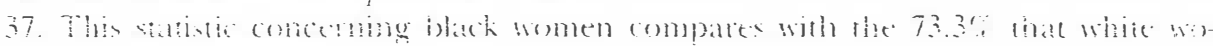

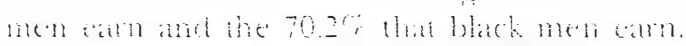

38. SHRRRAR wipa hote 23, at 131 . 
of black women do not have jobs that carry with them the soit of job-related benefits that help a woman to protect her assets and lifestrle in the event of unemplorment, illness, disability, or retirement. Between 1987 and 1993, only 50.2\% of blacks were covered by private health insurance, as compared with $73.7 \%$ of whites. In 1993. only 37.5\% of black female wage earners were protected by pension plans of some kind, though in this regard, ther were not much worse off than white or black men or white momen. ${ }^{40}$

Entrepreneurship and business ownership are theoretically another route to wealth accumulation. For a host of reasons, blacks, in general, have not been successful in pursuing entrepreneurial endearors, ${ }^{+1}$ though there is evidence that the trend is changing for both men and women.

In terms of expenditures, black women are more likely to be single parents and the heads of households than white women. Raising children entails rather large expenses. Though women, in general, pay more than men for many goods and services, ${ }^{\text {t2 }}$ the cost of black women's consumption is also increased by the premium or "tax" that discrimination forces blacks to pav in pursuing ordinary commercial transactions. ti

The handicaps that black women encounter in commercial mansactions extend to their dealings with financial institutions. Wamr black neighborhoods do not have locai bank or Sarings \& Loan branches: instead, residents must rely on check-cashing outlets that generally charge high fees and do not offer the range of financial services that banks provide.tt In any event, most bankis no longer offer accomts that suit the needs of smallbalance depositors or savers. Institutional support for generalized small-scale sarings is quite limited. Moreorer, the absence of neighborhood banks also restricts the arailability of sources of creclit for large purchases.

The discrimination blacks have faced in the market for mortwages has hat a particularly devastating impact on their accumu-

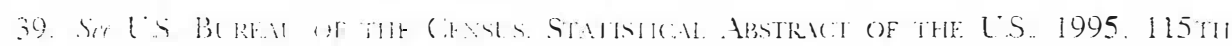
Fillu at 118 th1.169)(1995).

to. Sir ill at 383 , bl.600.

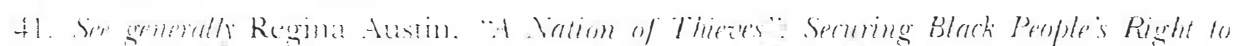

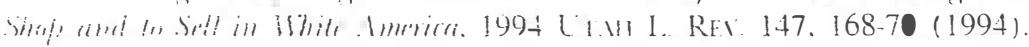

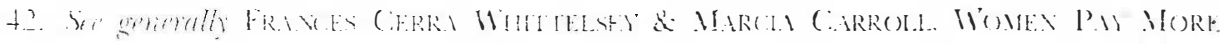

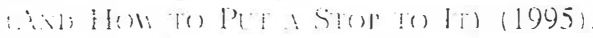

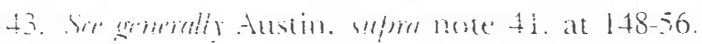

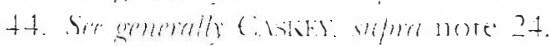


lation of wealth. ${ }^{45}$ In their book Black Wealth/White Wealth: A New Perspective on Racial Inequalit)', sociologists Melvin Oliver and Thomas Shapiro extensively analyze the impact on blacks of discrimination in the markets for housing and residential mortraves. The authors estimate that discrimination in the form of denied mortgages, higher mortgage rates, and lost housing appreciation has cost blacks $\$ 82$ billion. $^{+6}$

Oliver and Shapiro do not include in their figures the value of land that blacks have lost as a result of what David H. Harris, Jr. of the Land Loss Prevention Project terms "formidable forces in the law." + ? Blacks' land ownership of farm land has declined drastically since the turn of the century as a result of "partition sales, tax and debt foreclosures, adverse possession, [and] eminent domain ... [as well as] illiteracr, racism, intimidation, and political and economic powerlessness." +8 Urban land holdings have been impacted by "[h]ome improvement schemes, gentrification, envirommental racism and the economic development activities of local governmental entities" that always seem to result in whites winding up with ownership of black folks' land. ${ }^{99}$

In terms of policy changes at the macroeconomic level, efforts should be made to curb the institutional impediments that block black women's ability to build their wealth and to get government on the side of wealth acquisition, particularly for poor black women. The most significant reforms would be those that increase black women's returns for their participation in the labor market, particularly through the provision of benefits like health insurance and pension coverage. Other reforms that would be adrantageous include ending discrimination in the markets for housing and home mortgages, facilitating business development by black women, including entrepreneurship in public housing communities by pubic housing residents, and either forcing existing financial institutions to service the needs of small scale savers, ${ }^{50}$ or subsidizing the development of new thrift institutions like community-based or work-based credit unions that would better serve black women.

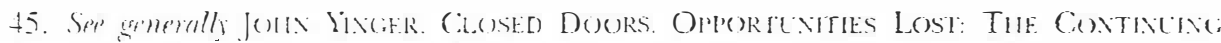

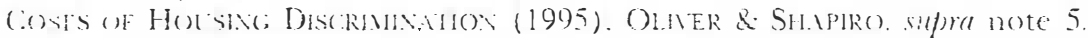

46. (MINER \& SHAPRos sutpra note 5, at 151 .

47. Dalvid H. Hatris. Jr. The Balle for Blatk Land: Fighling Emiment Bomain. NB.t

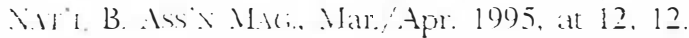

48. $11 \%$

49. in!

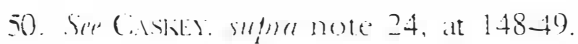


Ideally, the government should do for poor black women what it has done for rorking-class and middle-class white men. Gorermment programs targeting poor women have not been aimed at improing their asset base and thereby permanently altering their class status. As William Julius Wilson stated in his book When Wom Discaptears:

[T] argeted programs for the poor in the Lnited States do not eren begin to address inequities in the social class ststem. Instead of helping to integrate the recipients into the broader economic and social life of mainstream societr-to "capitalize" them into a different educational or residential stratum, as the GI bill and the postrat mortgage programs did for workingand middle-class whites-they tend to stigmatize and separate them. 51

I cloubt that there exists, at this time, the political will to capitalize poor black women's assent to higher class standing by subsidizing their asset acquisitions, especially given the cultural explanations for black women's asset poverty. Eren small-scale policy reform at the structural and institutional level is likely to be impeded by the belief that the sparsity of black women's wealth is due to their lack of frugality and unwillingness to make present sacrifices for future gain. Despite the breath and depth of the material, structural. and institutional imperiments to black women's asset accumulation, it is black women's moral and cultural fiber that gets called into question when the subject tums w black women's net worth.

Popular ideology auributes indigenous black women's lack of wealth to their profligate spending and perverse mismanagement of moner. 5 Back women aro constructed as undisciplined comsumers who lack the financial discipline to sare. Lnsatistied with delaved gratification, they spend money that is not theirs bambookling it from men) and that they do non have (rmming up high credit card balances). Giren the financial hardships they suffer by virtue of being near the botam of the sociocomonic lather. ther are blaned for not confoming to the model of economirally rational actor who engages in longrange, liftecrole

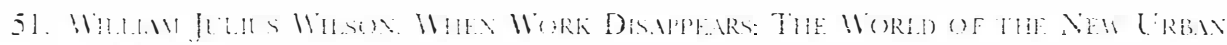
P(x) $15657(1906)$.

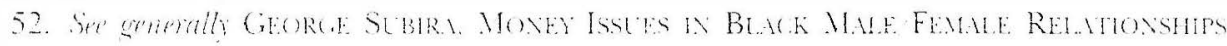

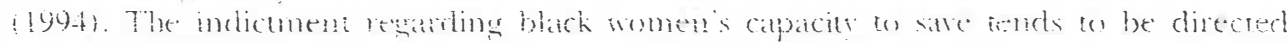

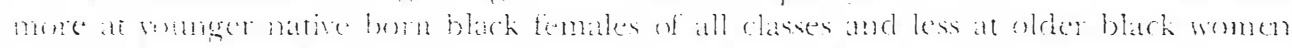

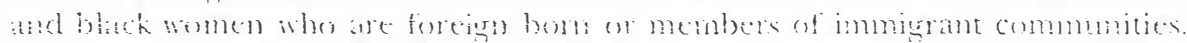


plamning by rationally allocating her resources between current desires and future needs. ${ }^{53}$ It does not matter that the rest of the societr. obsessed with consumption, is not saring as much as it once did and is rumning up debt. Black women's lot is worse orerall and, therefore. black women have more of a responsibility to exercise greater self-control and to resist the temptations of rampant consumerism. According to these notions, black women's lack of wealth is a product of the moral failure and of the values of individual black women and their culture. ${ }^{5+}$

Clearly, some of the accusations leveled against black women regarding their consumption and spending habits are capable of empirical proof, but the data nearly is impossible to acquire. Little attention genterally is paid to the specifics of debt accumulation or to its gendered implications. ${ }^{55}$ The characteristics and circumstances of black female debtors is an area of reseanch that needs to be extensively mined.

In any erent, the role that economic rationality plays in anyone's sarings beharior is not clear. Cultural and psychological factors probably have greater operational power. ${ }^{56}$ Even " [t]he conomic [rationality] paradigm implies that beharior depends on expectations about the future. "57 Those expectations are likely to be the product of personal experience and of psichosocial orientations. 58

Sarings betavior seems to be less the product of a rational or svstematic reighing of the costs and benefits of saring and more the result of the operation of "rules of thumb. . that . . reflect social and cultumal nomm"so or habits regarding the ahocat tion or disposition of financial resourcese "The foundation of all weallh is land." "Voney may not be ererything, but it's fay ahead of what's in second place." Witty litte sarings and clever ditues are part of the context in which sangs behavion ocous.

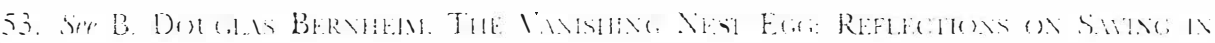
A11kik ; 67 (199) 11 .

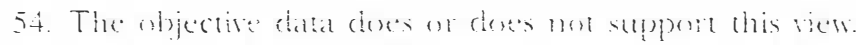

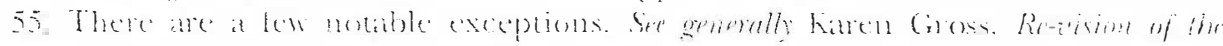

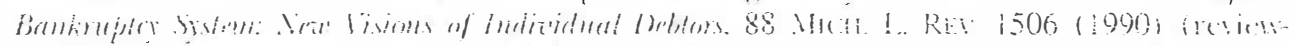

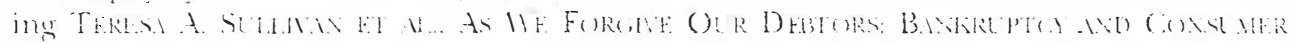

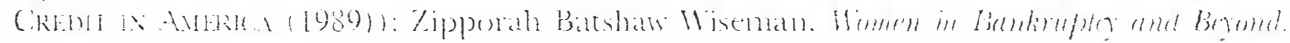
6.5 Mo. L . . 107 (1989)

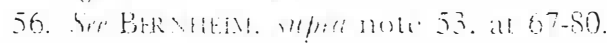

57. il. al 69

58 . So ir.

59. 11. ait 84

60. Sirtit all 71 
Thus, the amount of material wealth a group of the population controls may reflect the amount of social capital that is invested in promoting its acquisition of wealth.

Taken all together, the cultural or sociological factors that impact on black women's saring behavior are a rast unexplored area of research, especially as these factors are impacted by or respond to the law: The condemnation of black women regarding their habits of thrift and economy, therefore. seems a bit premature. One of the biggest unknowns is the bearing institutional and structural impediments have on black women's orientation to the future and its impact in turn on their limited wealth accumulation. The inquiry is all the more difficult because there is no essentialist core to black women's financial existence that has across-the-board explanatory power. Black women's culture is as diverse as its practitioners. It varies among subgroups, differing in age. class, sexual orientation, geographical location, and national origin. The culture, or cuitures, of black women vary in part because the material, structural, and institutional factors already outlined impact different subgroups of black women clifferentlv.

I join the plea made by Professor Patricia Hill Collins in this Srmposium for greater support and funding of research that focuses on black women and their families as accumulators and transmitters not only of culture, but also of wealth. ${ }^{61}$ However. the inquiry into the cultural and legal aspects of black women? relative lack of assets has to begin somewhere. What follows are the speculations and many unresolved questions I have regalding the influence of cultural and legal factors on the efforts of indigenous poor, working-poor, and lower, micldle-class black women to acquire wealth. What follows is. in a way, my own research agenda concerning issues of wealth accumulation.

In my experience, poor and working-class black women stash moner away or hicle it about the house in secret places where they hope other family members or burglars are unlikely to find it. This is especially true for women who do not have bank accounts either because banks are not convenient to use. banks are not to be trusted, or the women cannot satisfy the minimum requirements for a formal checking or sarings account. Many black women have lost their little pot of money to an untrustworth

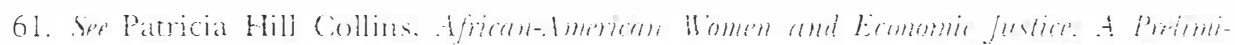

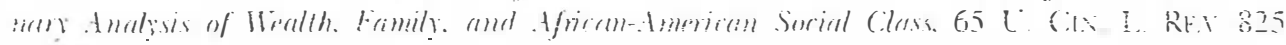
(1997). 
relative who did not share their plans for the future or to burglars who seemed to know just where to look. ${ }^{62}$ The informal nat ture of sarings activity makes the accumulation of assets quite haphazard and risky; howerer, the institutional support for doing much more simply does not exist.

Mental accounting or the allocation of funds based on their source is very important in sarings beharior. Income from some sources is spent immediatels, while income from other sources is not. Income tax refunds represent a form of sarings that many black women use to finance expensive or special purchases. The relationship between tax refunds and asset accumulation for these women should be explored further. Other black women put the sums ther make from working a second job or engaging in informalo. economic actirity, like selling cosmetics or strling hair in the kitchen, into a special fund for long-range consumption. We need to know more about the relationship between the underground economy, which is to a large extent the creation of legal regulation, ${ }^{\text {bt }}$ and black women's accretions of wealth.

The figures regarding the disparity between the asset holdings of black married couples and black female household heads seem to suggest that singlehood is a major cause of black women ss asset porerty. Singlehood, mlike whiteness, which also is associated with greater wealth, is assumed to be a circumstance that blacks control. It is not clear why married couples acquire so much more realth than singles do. Asset accumulatom no doubt is easier when there are two wage earners rather than one. Moreorer, there mar be efficiencies arising from the consolidat tion of living expenses and the division of labor that are produced when two adults maintain a single household. It may also be the case that marriage increases worries and responsibilities, which, in turn, result in greater incentives to acquire assets. Whaterer the explanation, it appears that the legal, cultural, and all-important economic factrors that influence rates of marriage among blacksto are hating an impact on rates of wealth accuma-

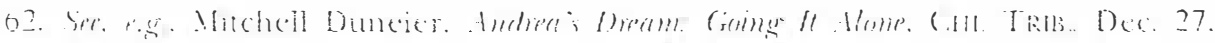

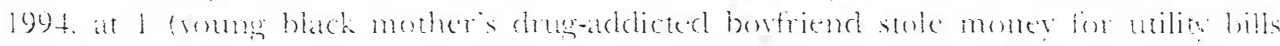

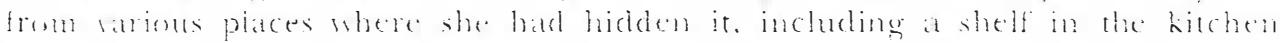
alphisadi.

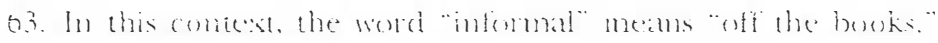

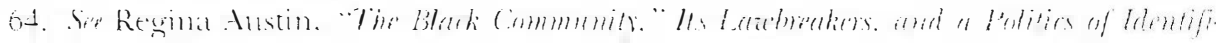

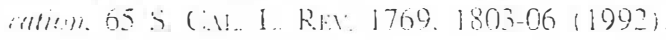

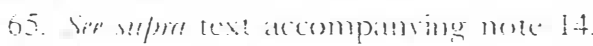

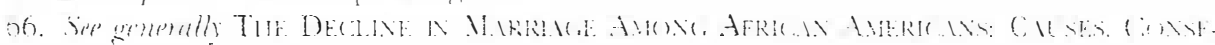


lation. It also is possible, howerer, that the norms and the material reality impacting on wealth accumulation are influencing black rates of marriage.

In some segments of the heterosexual black population, saving and asset accumulation are gender roles assigned to women and are sources of conflict between women and their spouses or partners. If money is the biggest source of tension in most marriages and long-term relationships, it must be especially problematic among those torn between accumulating wealth and satisfying short-term, seemingly immediate needs. Need and risk may be riewed differently by black women and men, and the tensions caused by this disparity, if it exists, might work against the formation of more formal unions.

Many of the black women I queried on the subject of black women's wealth jokingly cited men as the chief cause of black women's asset porerty. There is a widespread notion that black women are foregoing long-tcrm liaisons because black males cannot play the breadwinner role or otherwise substantially contribute to the financial well-being of a family, including asset accretions. Popular belief has it that black women are, instead, choosing to do badly all by themsclves, as ther sar; they do not need a man to make their lives worse. Howerer, there is some evidence that economic pressures are not preventing the formation of strong and stable relationships between unmarried black males and females. Black women's asset accumulation would be strengthened if more social capital in the form of culture and law was invested to promote easier asset accumulation for those other than the traditional nuclear family unit.

Black women's time and moner mar be subject to familial and communal demands that stifle wealth accumulation. Black working people bear a greater burden than their white comterparts for helping relatives who are unable to sustain themselves without financial assistance. th $^{\circ}$ the catse of sich or infirm relatives, the obligation may entail a woman's taking time off from work or totally suspending emplorment. Thus assets that might have been used for long-term improrement of a black woman's eco-

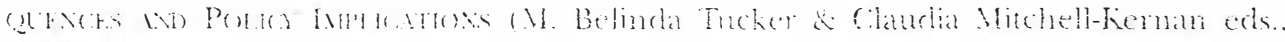
1995).

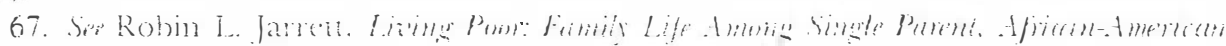

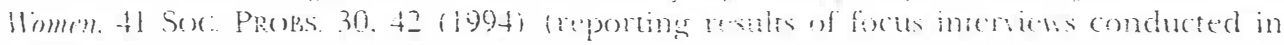
19881.

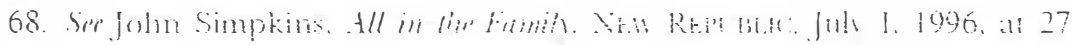


nomic status might be employed instead to support and to care for a needy or otherwise dependent relative. A black woman's children indeed mar represent her biggest capital investment or her greatest protection against a poor and lonely old age. The parent's expectation of support may be the quid pro quo for the sacrifices she made to increase the earning capacity of her children. Furthermore, her children's needs to amass assets for their old age may be offset br a reciprocal obligation owed to them from their own young. Broader support for long-term health care and more generous family leare provisions that are compatible with black women's cultural obligations to family would strengthen black women's wealth position.

Black women's philanthropy to the church and to other social organizations and associations may also affect their individual wealth accumulation. Of course, charitable giving, like generosity within the extended kinship network, may create collective resources or assets that can be called upon in time of need. We really need to test the extent to which reciprocal communal obligations-which actually deliver material benefits in sufficient amounts sufficient to the financially distressed-as opposed to private wealth, are an important element of black people's notion of the good life.

Beliefs about the protection that social welfare programs will provide in the future could affect a black woman's incentives to save. Theoretically, "[w]hen the government provides either larger retirement benefits or a more comprehensive safety net, it reduces the incentives for a private individual to save on [her] own behalf." Black wonen have not benefited as much as others from social welfare programs, but it is not clear that black women are aware of their relative disadvantage.

Asset accumulation by black women may also be impeded by the absence of cultural mechanisms for the smouth transfer of wealth from one generation to the next. The inability to keep wealth intact as it is passed on, or to keep it in the hands of black people who could use it. reduces its value to each succeeding generation and to black people's overall wealth. I have heard the stories black folks teil about relatives fighting over a bit of land or the small sum left in a bank accomt by a deceased family member. The association between wealth and family dissension may act as an imperdment to wealth acquisition.

69. BERNHEM, sumat note 53. at 87 . 
The lack of access to estate plamning and to related legal services $^{70}$ and the resulting inability to negotiate the inheritance laws hare operated to deprive blacks of their ancestors' wealth. For example, sociologist Carol Stack has written about blacks who returned from the North to their Southern roots in rual North and South Carolina; she found:

$[\mathrm{P}]$ eople who could not readily file wills at the courthouse or who feared the entanglement of legal paper were eventually beset with problems arising from inberitance of land. "Heirs property," held in common br a group of relatives, with no clear indiviclual title, became the usual form of land ownership among black [S]outherners, and heirs property proved notably susceptible to tax forfeiture and forced-partition sales. An heirs farm could be force-sold under a thousand and one circumstances-what if, for example, one of the family members listed on the cleed applied for admission to a nursing home? ${ }^{71}$

In the South, nonblacks typically stand ready to take land that blacks lose. In urbanized communities, the situation is somewhat different. The houses that the elderly leave behind when thes die are abandoned by relatives who do not quite know what to do with them.

It is my sense that black women, particularly older ones, have acquired more wealth than they have been able to keep or to pass along to their descendants becalse the women have been the rictims of rarious fiauds, schemes, and scams that take advantage of their age gender, or lack of financial and business sophistication. ? Banks, mortgage companies, and home improrement or repar connactors come radily to mind as culprits here. Also, the insurance companies whose home service agents sell black women multiple, expensive life insuance policies.

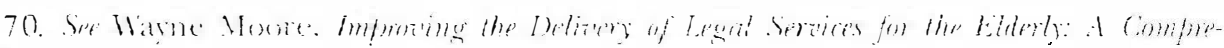

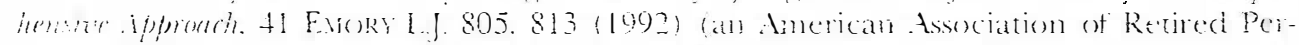

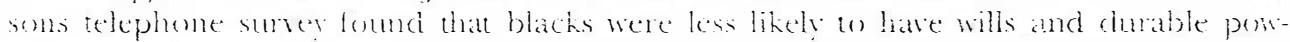
ers of attorney than white;)

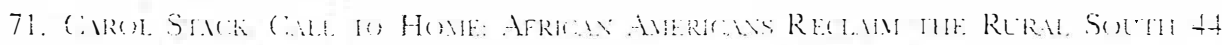
$1096)$.

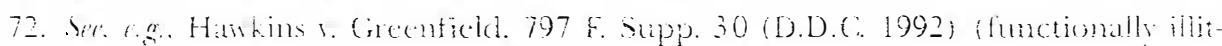

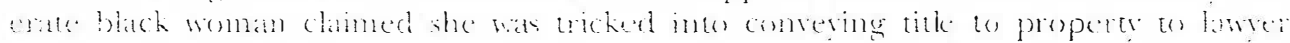

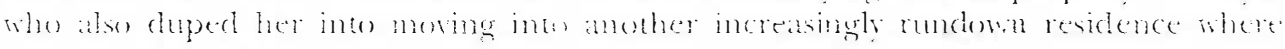

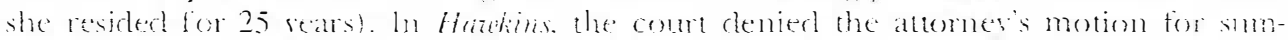

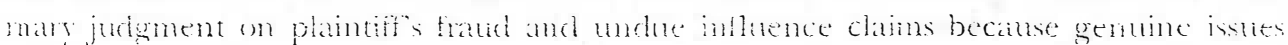
of anterial fact remanted conceming the and when the applicable stante of limitation began wa tell. Ser ir al $33-34$.

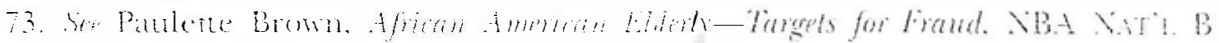

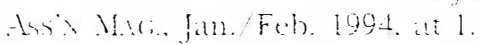


which, if they have not lapsed, pay out small face amounts inadequate to bury the insureds, let alone leave their descendants a legacy, are deserving of special condemnation. ${ }^{74}$

In part, the crooks hare been able to commit their misdeeds because the benefits of consumer protection services have not been sufficiently comprehensive where black women are concerned. In part, black women hare been victimized because their culture has not prepared them for the task of amassing and managing assets or because the financial markets that are accessible to them have not supplied them with trustworthy advisors or in termediaries.

In my view, the biggest impediment to black women's wealth accumulation is the absence of a black economic action agenda and program directed at helping black women secure long-term financial security for themselres, their families, and their communities. Black women are not educated or informed about how to manage monev-how to spend it, save it, invest it, negotiate with it, or gire it awar. ${ }^{75}$ As popular economic commentator George Subira put it, "[P]roper information about money management has no systematic way of entering their lives. The information is not part of their high school or college education, is not part of the Black media (except Black Enterprise), is not offered in our churches or social organizations, and is generally not discussed intelligenty at the family dimner table."76 In explaining why blaks do not manage their money better, Subira points to such factors as a false sense of securits, a belief that only the rich need or can afford assistance with managing their financial wellbeing: a healthy suspicion of those provicling financial assistance, an underutilization of financial assistance by other blacks who might serve as role models, and a lack of economic guidance from black leaders. ${ }^{77}$ This indictment should include lawers. I

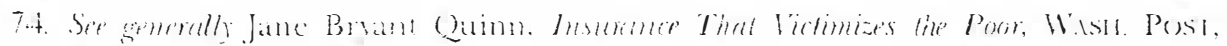

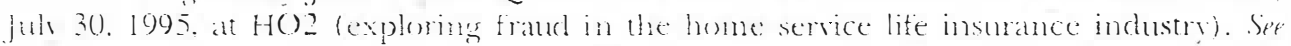

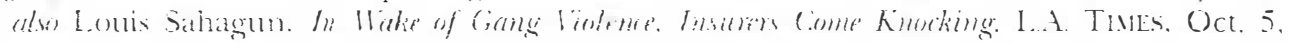

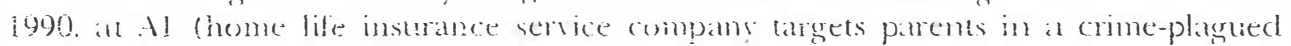

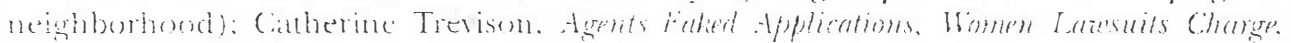

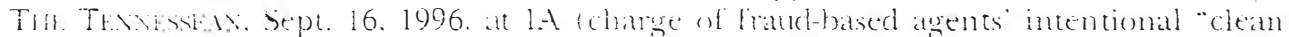

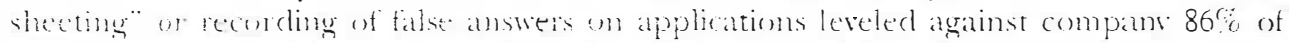
whose policwholders were black). For a tiedomal account of the significance of bural in-

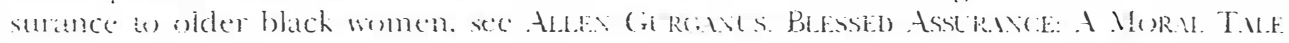
IN WIIIE PLCHE 192 (1991).

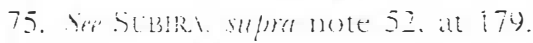

76. lil at 180 .

77. Sir i. at $183-84$. 
like to think that this situation is changing. ${ }^{70}$

Much of my recent research has explored the ways in which black economic activity has come to be associated with deviance of one sort or another. The acquisition of wealth stands on a par with other forms of economically adrantageous or enterprising behavior that are treated as forbidden. mrsterious, or aberrant when undertaken br blacks. Blacks are belittled or impeded as they struggle to understand and conquer their economic marginalization. The label "deviant" gets applied to the black actors on both sides of a commercial transaction: burers and sellers. clients and lawrers, investors and inrestment adrisors. The worst thing about the deriance approach to black economic actirity is that many black people, especially women, have bought into the idea and embraced it. Howerer, black economic activity is not deviance; it is only constructed as such to make it easier to exploit black people. It is necessary for blacks to get beyond the blanket suspicions and barriers created by the labeling of black economic activity as deriant in order to begin to achieve enduring economic progress.

I like to talk in terms of building and strengthening the black public sphere. The black public sphere contemplates uniting political and economic arenas with the goal of building black institutions, increasing emplorment opportunities for blacks, and expanding the power that comes from collectively generating wealth and controlling the messages and the mechanisms for deciding how it should be used. The black public sphere approach is based on a notion of the black good life that can only be achieved if blacks control outlets for their cultural creativity and their economic productivity. The black public sphere approach proceeds on the assumption that blacks can compete with anyone else and can build a base of wealth like everrone else if racist institutional and structural barriers are brought down.

Of course, our society is characterized by many competing and overlapping public spheres. Most black women participate in more than one. When it comes to managing and using wealth, many white and nonblack minority women are operating under

78. (ne sign of change is the appearance of books on moner management and in-

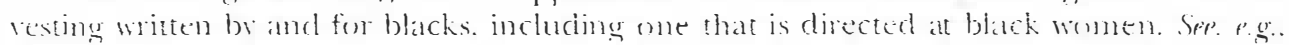

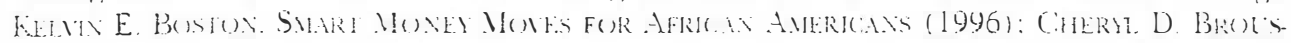

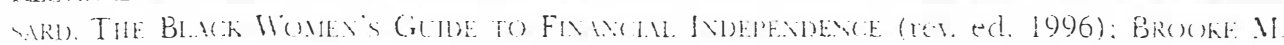

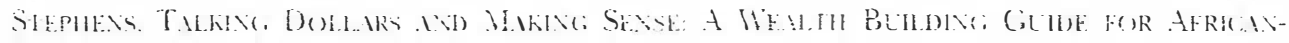
IVIRK INS (1997). 
the same disabilities that impact blacks of both genders. As Sheryl Marshall put it in an essay entitled Gelting Money and Using It:

Women have not grasped the economic implications of enfranchisement, nor the intimate connection in our political/legal system among economics, politics, and the law: It is probably safe to say that the majority of women-in spite of extemal manifestations to the contrary-have not internalized the concept of personal. lifelong independence. ${ }^{\text {iq }}$

Many do not have checking accounts, have never made an investment. do not know what they are entitled to under their spouses' Social Security or pension plans, and have no financial plan of their own. Marshall attributed women's lack of financial risktaking to many factors, including women's socialization, formal education, experience, support systems, and perception by the business community. ${ }^{81}$ The next stage of the feminist movement will likely concentrate on infiltrating and changing structures of economic power. ${ }^{32}$ Although white women start out with access to significantly more wealth than black women, there may be points of convergence between the black and white female public spheres. Achieving changes in public policy that will make it more likely that black women will be able to build the assets required to support a sood life for themselves and their families will require that those points of convergence be strengthened and emphasized.

It will take a great deal of time and effort to build coalitions arolund women's efforts to build assets. However, with every election and through successtul organizing campaigns like that being waged against the underinvestment in breast cancer research, women's political clout is growing. Women need to use theis political capital to support the accumulation of material capital with which all women might assure their long-term financial security.

Increases in black women's material capital will depend. therefore, on the combined impact of their social and political capital and that of others whose concerns mirror, overlap, and coincide with their own. In that regard. let me end with the words of ose-

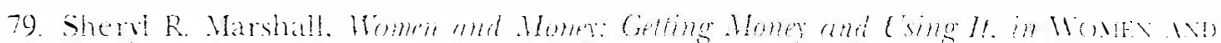

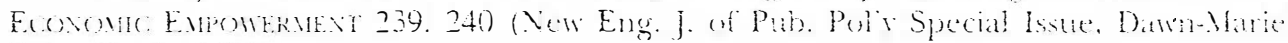
Driserll ed. 1990 .

80. Sir it.

31. Sit 11 .

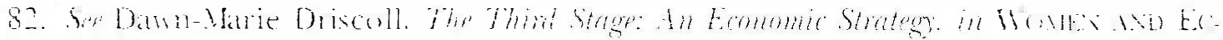
wave i: 
ola McCarty, the laundry woman who donated her life's savings to the University of Southern Mississippi for scholarships for needy students. ${ }^{83}$ Ms. McCarty's lonely and isolated existence came to an end when she took her hard-earned sarings and unselfishly gave it away. The social power that wealth can create is evident in Ms. McCarty's story; by so generously donating her accumulated assets, she has been rewarded with honors, attention, and a bit of fame. ${ }^{84}$ Her contribution to the University of Southern Mississippi has been more than matched by those of others stimulated by her example. Ms. McCarthy is publishing a collection of her sayings that will be entitled Simple Wisdom for Rich Litiing. On the subject of savings, she says, "The secret to building a fortune is compounding interest." 85 She is right about that.

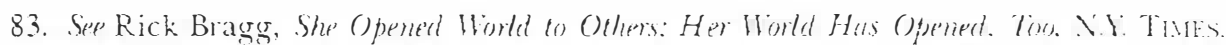
Nox: 12, 1996, at , 11 .

84. This point was raised by Hugh F. (Trer) Dall of the Lenall Aid Socier on (incinnati who commented on this Article at the Agenda for the 21 st Centum Labor Fore Conference.

85. Brager, supres note 83, at A22. 